企画 金沢大学附属病院消化器内科 金子 周一

\title{
特集 肝がん：診断と治療の進歩
}

\section{Editorial}

我が国における肝がん診療の動向

金子 周一

トピックス

I . 疫学の動向

II . 肝炎診療体制一肝炎対策基本法をうけて

III. 病因と病態一最近の遺伝子解析を中心に

IV . 診療ガイドラインの進歩

1. 診断のガイドライン

2. 治療のガイドライン

3. サーベイランスのガイドライン（治療後も含む）

$\mathrm{V}$. 診断法の進歩
1. 超音波診断
2. CT診断
3. MRI診断

VI. 治療法の進歩

1. 肝切除

2. ラジオ波焼灼術

3. 肝動脈化学塞栓療法

4. 分子標的治療薬

5. 化学療法

6. 肝移植

7. 肝がんの放射線治療
谷合麻紀子 4

江口有一郎 - 他 11

田中 真二 19

建石 良介・他 27

中山 壽之・他 31

荒井 邦明 - 他 37

沼田 和司 - 他 44

上田 和彦 55

赤羽 正章 61

長谷川 潔・他 70

大久保裕直 78

山門亨一郎 87

池田 公史 ·他 93

山下竜也・他 102

海道 利実・他 110

福光 延吉・他 116

\section{座談会}

肝炎ウイルス陽性患者に対する診療体制をどうするか

正木 尚彦・他 


\section{今月の症例}

月経周期に一致した発熱を契機に発見された家族性地中海熱の1例 佐藤 洋志・他 149

○アセトアミノフェンによる過敏性血管炎の1例

芝原 友也・他

\section{医学と医療の最前線}

米国におけるホスピタリスト医療：成熟する新しい専門領域

デシュパンデ・

ゴータム・他

155

腎疾患とEPO産生細胞

中田 紘介・他

160

血管炎症候群Update

槇野 博史 · 他

166

\section{専門医部会}

・シリーズ：日本発臨床研究の紹介と反省点を語る

変性LDL（アポBを含むLOX-1リガンド）と頸動脈内膜中膜複合 体の関連：日本と米国白人の中年男性における検討

岡村 智教・他

173

シリーズ：指導医のために：医学・医療の多様性を追求する

○臨床系学会と医薬企業との利益相反を制御した関係を目指す 〜JAMAの論文を参考に〜

小山 雄太

専門医部会近畿支部教育セミナー

二次性高血圧up-to-date一何をどこまで検査する一

・シリーズ：患者の言葉・身体所見を読み解く

○リーズ : 「患者の言葉・身体所見を読み解く」

○発熱と筋力低下～症候の組み合わせから診断を考える〜

○間欠的な動悸・脈の不規則感へのアプローチ

神出計 - 他

シリーズ：内科医と災害医療

○第3期「災害時におけるマネージメントおよび災害医療教育」

専門医部会 災害医療支援ネットワークワーキンググループ 座談会「東日本大震災における体験から」

朔 啓二郎

松村 正巳 - 他 200

古橋 龍彦 - 他

205

井口清太郎

草野 良郎・他 